\title{
Pengaruh Pupuk Kompos Terhadap Pertumbuhan dan Hasil Beberapa Varietas Kedelai (Glycine $\max (\mathrm{L}$.$) Merrill)$
}

\author{
Laila Nazirah \\ ${ }^{1}$ Staf Pengajar Agroekoteknologi Fakultas Pertanian Universitas Malikussaleh \\ Email : lailanazirah@unimal.ac.id
}

\begin{abstract}
RINGKASAN
Kebutuhan kedelai di Indonesia terus meningkat seiring dengan kesadaran masyarakat dalam mengonsumsi makanan bergizi. Salah satu upaya untuk meningkatkan hasil kedelai adalah dengan varietas dan kompos yang bersumber dari eceng gondok. Tujuan penelitian ini adalah untuk mengetahui respon pertumbuhan dan hasil dari berbagai varietas kedelai pada penambahan kompos eceng gondok. Penelitian ini dilakukan di Aula Teungku Mahmud, Desa Uteun Geulinggang, Dewantara, Aceh Utara, mulai dari bulan Maret hingga Juli 2018. Penelitian ini dilakukan dengan menggunakan Rancangan Acak Kelompok (RAK) faktorial yang terdiri dari dua faktor dengan 3 ulangan. Faktor pertama adalah varietas kedelai (V1 = Baluran, V2 = Anjasmoro, V3 = Kipas Merah). Faktor kedua adalah dosis kompos eceng gondok (terdiri dari 3 level: $\mathrm{E} 0=0 \mathrm{~g}$, E1 = 17,5 g, E2 = 24,5 g). Untuk membandingkan setiap perlakuan, tes lebih lanjut dilakukan menggunakan uji lanjutan Duncan pada tingkat $5 \%$. Hasil penelitian menunjukkan bahwa jenis varietas memiliki diameter batang, jumlah cabang produktif, jumlah polong per tanaman, bobot biji kering per tanaman, Sedangkan pemberian kompos eceng gondok mempengaruhi tinggi tanaman, jumlah daun, diameter batang, dan volume akar. Interaksi antara penambahan kompos eceng gondok dan varietas tidak mempengaruhi semua variabel yang diamati.
\end{abstract}

Kata kunci: varietas kedelai, kompos, carakter

\section{Effects of Compost Fertilizer on Growth and Yield of Some Varieties Soybean (Glycine max (L.) Merrill)}

\begin{abstract}
Soybean needs in Indonesia continue to increase along with the public awareness in consuming nutritious food.One the effort to improve soybean yield is by varieties and compost sourced from water hyacinth. The purpose of this research was to determine the growth responses and the results of various soybean varieties on the adduction of water hyacinth compost.This research was conducted in Teungku Mahmud Hall, Uteun Geulinggang Village, Dewantara, North Aceh, starting from March to July 2018. The research was conducted using factorial randomized block design (RBD) which consisted of two factors with 3 replications. The first factor is soybean varieties $(\mathrm{V} 1=$ Baluran, $\mathrm{V} 2=$ Anjasmoro, V3 = Kipas Merah). The second factor is doses of water hyacinth compost (consisting of 3 levels: E0 $=0 \mathrm{~g}, \mathrm{E} 1=17.5 \mathrm{~g}, \mathrm{E} 2=24.5 \mathrm{~g}$ ). To compare each treatment, a further test was performed using Duncan's advanced test at the level of 5\%. The results showed that the type of varieties had an stem diameter, number of productive branches, number of pods per plant, dry seed weight per plant, While giving water hyacinth compost affects the plant height, number of leaves, stem diameter and root volume. The interactions between the adduction of water hyacinth compost and varieties did not affect all observed variables.
\end{abstract}


Key words: soybean varieties, compost, carakter .

\section{Pendahuluan}

Rendahnya produksi kedelai Indonesia salah satunya dikarenakan belum maksimalnya pengetahuan petani dalam penggunaan teknologi produksi yang mendukung pertanian berkelanjutan dan semakin berkurangnya sumber daya lahan yang subur karena penggunaan pupuk anorganik secara terus menerus (Jumrawati, 2008).Untuk meningkatkan produktivitas tanaman kedelaiadalah dengan cara memperbaiki sistem budidaya,salah satu caranya yaitu dengan menggunakan varietas unggul dan penggunaan pupuk organik.

Keberadaan varietas kedelai mutlak diperlukan untuk meningkatkan ketertarikan petani pada budidaya kedelai lokal. Pemerintah melalui Departemen Pertanian telah melepaskan berbagai varietas unggul. Pada tahun 1998 Balai Penelitian Kacang-kacangan dan UmbiUmbian (BALITKABI) Malang telah melepas sepuluh varietas kedelai unggul, dengan kualitas lebih unggul dibanding kedelai impor, dengan cirri-ciri biji besar dan kandungan protein mencapai 42 persen. Bibit varietas unggul yang telah dilepas adalah Burangrang, Anjasmoro, Argomulyo, Panderman, Argopuro, Gumitir, Baluran, Bromo, Merubetiri, dan Mahameru (Widianto,2008).

Selain varietas penggunan pupuk organik juga mempengaruhi tingkat produktivitas. Pupuk organik adalah pupuk yang sebagian besar atau seluruhnya terdiri atas bahan organik yang berasal dari tanaman dan atau hewan yang telah melalui proses rekayasa, dapat berbentuk padat atau cair yang digunakan mensuplai bahan organik untuk memperbaiki sifat fisik, kimia, dan biologi tanah (Permentan, 2006).Eceng gondok (Eichornia crassipes) merupakan tumbuhan air yang tumbuh di rawa-rawa, danau, waduk dan sungai yang alirannya tenang. Pertumbuhan Pupuk kompos sangat cepat, sehingga Pupuk kompos dapat menutupi permukaan air dan menimbulkan masalah pada lingkungan. Selain merugikan, Pupuk kompos juga memiliki manfaat yaitu dapat dimanfaatkan sebagai pupuk organik dalam bentuk kompos.

Pupuk kompos juga dapat mempengaruhi pertumbuhan dan produksi tanaman kacang hijau. Percobaan tanaman kacang hijau yang diberikan kompos eceng gondok dengan dosis 0 (tanpa perlakuan), 5 $\mathrm{t} \mathrm{ha}^{-1}, 10 \mathrm{t} \mathrm{ha}^{-1}$ dan $15 \mathrm{t} \mathrm{ha}^{-1}$, hasilnya pertumbuhan dan produksi tanaman kacang hijau dengan parameter tinggi tanaman, jumlah cabang, jumlah polong per plot, berat 100 biji, dan produksi per plot (luas plot $1,5 \mathrm{~m} 2$ ) yang lebih baik yaitu pada pemberian dosis $15 \mathrm{t} \mathrm{ha}^{-1}$ (Ressi, 2015).

\section{Bahan dan Metode}

Penelitian ini menggunakan benih kedelai varietas Baluran, Anjasmoro, Kipas Merah, Pupuk kompos, pupuk majemuk NPK Phonska, dan polybag. Penelitian ini menggunakan Rancangan Acak Kelompok (RAK) pola faktorial. Ada dua faktor yang diteliti yaitu varietas, terdiri dari 3 taraf : $\mathrm{V} 1$ = Baluran, $\mathrm{V} 2=$ Anjasmoro dan V3 = Kipas-Merah. Faktor kedua yaitu kompos, terdiri dari 3 taraf : $\mathrm{P} 0=$ Tanah tanpa Pupuk kompos (kontrol), P1 = 17,5 g/polybag (5 ton/ha) dan P2 = 24,5 g/polybag (7 ton/ha).

\section{Pelaksanaan Penelitian}

Persiapan Media Tanam

Media tanam yang digunakan antara lain tanah lapisan atas (top soil) yang telah diayak dan dibersihkan, kompos eceng gondok yang digunakan berwarna hitam kecoklatan. Media tanam kemudian dicampurkan dengan Pupuk kompos sesuai perlakuan. Kemudian diaduk secara merata pada masing-masing polybag ukuran $35 \times 45$ $\mathrm{cm}$.

Penanaman Benih 
Penanaman benih dilakukan pada pagi hari, dengan cara dibuat lubang tanam dengan kedalaman $\pm 2,5 \mathrm{~cm}$. Benih dimasukan kedalam lubang sebanyak 2 biji perlubang tanam dalam polybeg, kemudian ditutup kembali dengan tanah gembur.

Pemupukan

Pemupukan dilakukan sebagai penambahan unsur hara yang ada didalam tanah. sebagai pupuk dasar yang diberikan untuk menunjang pertumbuhan tanaman kedelai adalah pupuk majemuk Phonska dengan dosis $100 \mathrm{~kg} / \mathrm{ha}$, diberikan 50\% dari dosis anjuran standart dan diberikan saat penanaman. Pupuk kompos sebagai pupuk perlakuan, dosis pupuk setara dengan perlakuan dan diberikan \pm 7 hari sebelum penanaman.

\section{Pemeliharaan}

1. Penyiraman

Penyiraman dilakukan pada pagi dan sore hari dengan menggunakan gembor yang bertujuan untuk menjaga kelembapan tanah pada kapasitas lapang, tetapi apabila hujan dan tanah masih lembab maka tidak perlu dilakukan penyiraman.

2. Penjarangan

Penjarangan dilakukan pada umur 7 hari setelah tanam dengan cara memotong salah satu tanaman yang kurang baik pertumbuhannya seperti tanaman yang kerdil. Tanaman yang ditinggalkan hanya satu untuk setiap lubang tanam dengan pertumbuhan yang baik.

\section{Penyiangan}

Penyiangan dilakukan apabila terdapat gulma pada areal pertanaman, penyiangan dilakukan dengan cara manual yaitu dengan cara mencabuti rumput-rumput atau tanaman penggangu lain di areal tanaman kedelai.

4. Pengendalian Hama dan Penyakit

Pengendalian hama dan penyakit dilakukan apabila terjadi gejala serangan pada tanaman, usaha pengendalian dilakukan dengan cara penyemprotan insektisida crowen dengan dosis yang dianjurkan.

5. Pemanenan

Waktu panen dilakukan pada saat masak fisiologis sesuai dengan deksripsi setiap varietas yang diuji, pemanenan dilakukan dengan cara mencabut tanaman secara hati-hati agar kedelai tidak rontok pada saat pencabutan.

\section{Hasil Dan Pembahasan \\ Diameter Batang}

Hasil analisis ragam menunjukan bahwa perlakuan varietas tidak berpengaruh nyata terhadap diameter batang tanaman umur 10 dan umur 20 HST, serta berpengaruh sangat nyata terhadap diameter batang tanaman umur 30 dan umur 40 HST. Sedangkan pada perlakuan Pupuk kompos tidak berpengaruh nyata terhadap diameter batang tanaman umur 10 HST, dan berpengaruh nyata terhadap diameter batang tanaman umur 40 HST, serta berpengaruh sangat nyata pada diameter batang umut 20 dan umur 30 HSTRata-rata diameter batang beberapa varietas kedelai dengan pemberian Pupuk kompos dapat dilihat pada Tabel 1. 
Tabel 1. Rata-Rata Diameter Batang Beberapa Varietas Kedelai Akibat Pemberian Pupuk kompos

\begin{tabular}{lcccc}
\hline \multirow{2}{*}{ Varietas } & \multicolumn{4}{c}{ Diameter Batang $(\mathrm{cm})$} \\
\cline { 2 - 5 } & $10 \mathrm{HST}$ & $20 \mathrm{HST}$ & $30 \mathrm{HST}$ & $40 \mathrm{HST}$ \\
\hline V1 = Baluran & $0.27 \mathrm{a}$ & $0.41 \mathrm{a}$ & $0.62 \mathrm{~b}$ & $0.81 \mathrm{~b}$ \\
V2 = Anjasmoro & $0.25 \mathrm{a}$ & $0.40 \mathrm{a}$ & $0.73 \mathrm{a}$ & $0.90 \mathrm{~b}$ \\
V3 = Kipas Merah & $0.25 \mathrm{a}$ & $0.43 \mathrm{a}$ & $0.79 \mathrm{a}$ & $0.98 \mathrm{a}$ \\
\hline Pupuk kompos & & & & \\
\hline E0 $(0 \mathrm{~g})$ & $0.25 \mathrm{a}$ & $0.39 \mathrm{~b}$ & $0.62 \mathrm{~b}$ & $0.83 \mathrm{~b}$ \\
E1 $(17,5 \mathrm{~g})$ & $0.25 \mathrm{a}$ & $0.42 \mathrm{ab}$ & $0.69 \mathrm{~b}$ & $0.94 \mathrm{ab}$ \\
E2 $(24,5 \mathrm{~g})$ & $0.27 \mathrm{a}$ & $0.44 \mathrm{a}$ & $0.82 \mathrm{a}$ & $0.97 \mathrm{a}$ \\
\hline
\end{tabular}

Keterangan : Angka-angka yang diikuti oleh huruf yang sama pada kolom yang sama tidak berbeda nyata menurut uji DMRT 5\%.

Tabel 1 memperlihatkan bahwa diameter batang tanaman terbesar akibat perlakuan beberapa varietas di jumpai pada varietas Kipas Merah (V3), dan diameter batang tanaman terendah dijumpai pada varietas Baluran (V1). Sedangkan diameter batang tanaman terbesar akibat perlakuan Pupuk kompos dijumpai pada perlakuan Pupuk kompos $24.5 \mathrm{~g} /$ polybag (E2), dan diameter batang tanaman terendah di jumpai pada perlakuan kontrol (E0).

\section{Jumlah Polong Pertanaman}

Hasil analisis ragam menunjukan bahwa varietas berpengaruh sangat nyata terhadap jumlah polong pertanaman, sedangkan pada perlakuan kompos eceng gondok tidak berpengaruh nyata terhadap jumlah polong pertanaman. Rata-rata jumlah polong pertanaman beberapa varietas kedelai akibat pemberian Pupuk kompos dapat dilihat pada Tabel 2.

Tabel 2. Rata-Rata Jumlah Polong Pertanaman Varietas Kedelai Akibat Pemberian Kompos Eceng Gondok

\begin{tabular}{lc}
\hline \multicolumn{1}{c}{ Varietas } & Jumlah Polong Pertanaman \\
\cline { 2 - 2 } & \\
\hline V1 = Baluran & $52.85 \mathrm{~b}$ \\
V2 = Anjasmoro & $83.48 \mathrm{a}$ \\
V3 = Kipas Merah & $112.57 \mathrm{a}$ \\
\hline Kompos Eceng Gondok & \\
\hline E0 (0 gr) & $70.26 \mathrm{a}$ \\
E1 (17,5 gr) & $83.24 \mathrm{a}$ \\
E2 (24,5 gr) & $95.41 \mathrm{a}$ \\
\hline
\end{tabular}

Keterangan : Angka-angka yang diikuti oleh huruf yang sama pada kolom yang sama tidak berbeda nyata menurut uji DMRT $5 \%$.

Tabel 2 memperlihatkan bahwa jumlah polong pertanaman terbanyak akibat perlakuan beberapa varietas di jumpai pada varietas Kipas Merah (V3) dengan nilai rata-rata 10.83, dan jumlah jumlah polong pertanaman terendah dijumpai pada varietas Baluran (V1) dengan nilai rata-rata 7.24. Sedangkan jumlah polong pertanaman tertinggi akibat perlakuan kompos eceng gondok dijumpai pada perlakuan Pupuk kompos 24.5 g/polybag (E2), dan jumlah polong pertanaman terendah di jumpai pada perlakuan kontrol (E0).

\section{Bobot Biji Kering Pertanaman (g)}

Hasil analisis ragam menunjukan bahwa varietas berpengaruh sangat nyata terhadap bobot biji kering pertanaman, sedangkan pada perlakuan Pupuk kompos tidak berpengaruh nyata terhadap jumlah bobotbiji kering pertanaman. Rata-rata bobot biji kering pertanamanbeberapa varietas kedelai akibat pemberian Pupuk kompos dapat dilihat pada

Tabel 3. 
Tabel 3. Rata-Rata Bobot Biji Kering Pertanaman Varietas Kedelai Akibat Pemberian Kompos Eceng Gondok

\begin{tabular}{lc}
\hline \multicolumn{1}{c}{ Varietas } & Bobot Biji Kering Pertanaman \\
\cline { 2 - 2 } & $(\mathrm{g})$ \\
\hline V1 = Baluran & $15.97 \mathrm{~b}$ \\
V2 = Anjasmoro & $19.35 \mathrm{~b}$ \\
V3 = Kipas Merah & $24.60 \mathrm{a}$ \\
\hline Pupuk kompos & \\
\hline E0 (0 gr) & $19.26 \mathrm{a}$ \\
E1 (17,5 gr) & $20.47 \mathrm{a}$ \\
E2 (24,5 gr) & $20.18 \mathrm{a}$ \\
\hline
\end{tabular}

Keterangan : Angka-angka yang diikuti oleh huruf yang sama pada kolom yang sama tidak berbeda nyata menurut uji DMRT 5\%.

Tabel 3 memperlihatkan bahwa bobot biji kering pertanaman tertinggi akibat perlakuan beberapa varietas di jumpai pada varietas Kipas Merah(V3) dengan nilai rata-rata 24,60 danbobot biji kering pertanaman terendah dijumpai pada varietas Baluran (V1) dengan nilai rata-rata 15.97 . Sedangkan bobot biji kering pertanaman tertinggi akibat perlakuan Pupuk kompos dijumpai pada perlakuan Pupuk kompos $17.5 \mathrm{~g} /$ polybag (E1), dan bobot biji kering pertanaman terendah di jumpai pada perlakuan kontrol (E0).

\section{Berat 100 Biji Kering}

Hasil analisis ragam menunjukan bahwa varietas tidak berpengaruh nyata terhadap berat 100 biji kering, begitu juga pada perlakuan kompos eceng gondok tidak berpengaruh nyata terhadap berat 100 biji kering. Rata-rata berat 100 biji keringbeberapa varietas kedelai akibat pemberian kompos eceng gondok dapat dilihat pada Tabel 4.

Tabel 4. Rata-Rata Berat 100 Biji KeringBeberapa Varietas Kedelai Akibat Pemberian Kompos Eceng Gondok

\begin{tabular}{lc}
\hline \multicolumn{1}{c}{ Varietas } & Berat 100 Biji Kering \\
\cline { 2 - 2 } & $(\mathrm{g})$ \\
\hline V1 = Baluran & $8.17 \mathrm{a}$ \\
V2 = Anjasmoro & $8.17 \mathrm{a}$ \\
V3 = Kipas Merah & $9.19 \mathrm{a}$ \\
\hline Pupuk kompos & \\
\hline E0 (0 gr) & $7.80 \mathrm{a}$ \\
E1 (17,5 gr) & $8.75 \mathrm{a}$ \\
E2 (24,5 gr) & $8.94 \mathrm{a}$ \\
\hline
\end{tabular}

Keterangan : Angka-angka yang diikuti oleh huruf yang sama pada kolom yang sama tidak berbeda nyata menurut uji DMRT $5 \%$.

Tabel 4 memperlihatkan bahwa berat 100 biji kering tertinggi akibat perlakuan beberapa varietas di jumpai pada varietas Kipas Merah (V3)dan berat 100 biji kering terendah dijumpai pada varietas Baluran (V1) dan Anjasmoro (V2). Sedangkan berat 100 biji kering tertinggi akibat perlakuan kompos eceng gondok dijumpai pada perlakuan 24,5 g/polybag (E2) dan berat 100 biji kering teendah di jumpai pada perlakuan kontrol (E0)

\subsection{Pembahasan}

Perlakuan varietas memberikan pengaruh terhadap diameter batang, jumlah polong pertanaman, bobot biji kering pertanaman, dan tdk berpengaruh terhadap 100 biji kering. Hal ini disebabkan karna adanya pengaruh genetik dan faktor lingkungan terhadap parameter pengamatan tersebut. Lakitan (2004) menyatakan bahwa terjadinya variasi dalam 
suatu tanaman dapat disebabkan oleh adanya pengaruh lingkungan dan faktor keturunan atau genetik. Perbedaan kondisi lingkungan memungkinkan munculnya variasi dimana variasi tersebut dapat menetukan penampilan akhir dari suatu tanaman.

Varietas Kipas Merah (V3) lebih baik pertumbuhannya jika dibandingkan dengan varietas Baluran (V1) dan varietas Anjasmoro (V2). Dalam hal ini faktor genetik menyebabkan perbedaan yang beragam seperti penampilan fenotip tanaman dengan menampilkan ciri dan sifat khusus yang berbeda antara satu sama lain. Hal ini sesuai dengan pernyataan Gabesius et. al., (2012), bahwa perbedaan susunan genetik merupakan salah satu faktor penyebab keragaman penampilan tanaman. Susunan genetik dapat berbeda di antara biji yang berasal dari tanaman yang berbeda, Hal ini membuktikan bahwa varietas Kipas Merah (V3) unggul dalam pertumbuhan dibandingkan dengan varietas Baluran (V1) dan Anjasmoro (V2).

Meningkatnya pertumbuhan varietas Kipas Merah (V3) diduga karna varietas tersebut mampu beradaptasi dengan lingkungan tumbuh sehingga mampu tumbuh dengan baik dan memberikan respon yang baik terhadap pertumbuhan dan perkembangannya.Faktor lingkungan juga mempengaruhi pertumbuhan dan hasil beberapa varietas tanaman kedelai, Susanto dan Sundari (2010) menyatakan berkurangnya intensitas sinar matahari menyebabkan tanaman tumbuh lebih tinggi, ruas antar buku lebih panjang, jumlah daun lebih sedikit, jumlah polong makin sedikit, dan ukuran biji semakin kecil. Ditambahkan oleh Darliah et al. (2001), bahwa respon genotip terhadap faktor lingkungan biasanya terlihat dalam penampilan fenotipik dari tanaman bersangkutan dan salah satunya dapat dilihat dari pertumbuhannya.

Hasil produksi (jumlah polong pertanaman, bobot biji kering pertanaman, dan produksi rata-rata $t h^{-1}$ ) menunjukan varietas Kipas Merah (V3) memiliki hasil yang lebih baik dibandingkan varietas Baluran (V1) dan varietas Anjasmoro (V2), hal ini diduga karnavarietas Kipas Merah (V3) mampu beradaptasi dengan lingkungan hidupnya, meskipun secara genotip varietas Baluran (V1) dan varietas Anjasmoro (V2) mempunyai potensi yang baik, akan tetapi karena masih dalam tahap beradaptasi produksinya lebih rendah daripada yang seharusnya, Agneesia. (2009) menyatakan produksi tanaman kedelai ditentukan oleh interaksi suatu varietas terhadap kondisi lingkungan. ditambahkan juga oleh Mimbar (1991), bahwa cuaca yang basah selama pengisian biji mengakibatkan berkurangnya ukuran biji.

Pemberian Pupuk kompos dengan dosis $24.5 \mathrm{gr} /$ polibag memberikan pengaruh terhadap tinggi tanaman dan diameter batang, hal ini diduga karna dosis kompos eceng gondok 24,5 g/polibag telah mampu membuat kebutuhan hara $\mathrm{N}, \mathrm{P}, \mathrm{K}$ dalam keadaan cukup untuk pertumbuhan tanaman. Sarief (1986) menyatakan proses pembelahan sel akan berjalan cepat karena adanya ketersediaan unsur hara $\mathrm{N}, \mathrm{P}, \mathrm{K}$ yang cukup, dimana nitrogen berperan dalam merangsang pertumbuhan batang yang dapat memacu pertumbuhan tinggi tanaman, unsur hara $P$ berperan dalam respirasi, fotosintesis dan metabolisme dan unsur hara $\mathrm{K}$ membantu metabolisme karbohidrat dan mempercepat pertumbuhan jaringan meristematik.

Hasil sidik ragam juga menunjukan bahwa rata-rata jumlah daun tanaman yang diberikan kompos eceng gondok $24.5 \mathrm{~g} /$ polibag nyata memberikan pengaruh lebih banyak dibandingkan perlakuan lain, hal ini diduga pada dosis 24.5 g/polibag mampu memenuhi kebutuhan unsur hara $\mathrm{N}$, $\mathrm{P}$, dan K. Sejalan dengan pernyataan Esdu (2008), Nitrogen berfungsi membuat enzimenzim yang berperan dalam membentuk daun. Nitrogen jika diberikan dalam jumlah yang berlebih justru dapat mengakibatkan produksi tanaman menurun, hal ini dikarenakan pemberian unsur $\mathrm{N}$ dalam jumlah yang banyak atau melebihi kebutuhan tanaman dapat mengekibatkan fase vegetative tanaman lebih panjang sehingga pembentukan organ generative tidak maksimal. Akibatnya selain produktivitasnya menurun, kualitas yang dihasilkan juga menurun. Ditambahkan oleh Nyakpa dkk (1988) menyatakan bahwa proses pembentukan daun tidak terlepas dari peranan unsur hara seperti nitrogen dan fosfor yang tersedia bagi tanaman. Kedua unsur hara ini berperan dalam pembentukan sel - sel baru dan komponen 
utama penyusun senyawa organik dalam tanaman yang mempengaruhi pertumbuhan vegetatif tanaman, khususnya peningkatan jumlah daun. Pada fase pertumbuhan vegetatif dibutuhkan juga ketersediaan unsur hara $\mathrm{K}$. Unsur $\mathrm{K}$ berperan dalam mengatur pergerakan stomata, sehingga dapat membantu meningkatkan pertumbuhan jumlah daun tanaman.

Pupuk kompos juga berpengaruh terhadap volume akar, dosis terbaik dijumpai pada perlakuan $24.5 \mathrm{~g} /$ polybag (Tabel 3), hal ini diduga karna pada dosis 24,5 g/polybag mampu memenuhi kebutuhan unsur hara.Menurut Purwanto (2006), Nitrogen memiliki manfaat bagi tanaman yaitu memacu pertumbuhan dan pembentukan daun dan anakan, serta terbentuknya akar. Ditambahkan oleh Suprapto (2004) mengatakan fosfor merupakan salah satu unsur yang esensial bagi tanaman yang berfungsi dalam pertumbuhan dan perkembangan tanaman antara lain merangsang perkembangan akar, sehingga tanaman akan lebih tahan terhadap kekeringan, mempercepat masa vegetatif dan panen.

\section{Kesimpulan}

varietas memberikan pengaruh terhadap diameter batang, jumlah polong pertanaman, bobot biji kering pertanaman, tapi tdk berpengaruh terhadap berat 100 biji dan pada umumnya varietas kipas merah (V3).memperoleh hasil yang terbaik. Pemberian beberapa dosis kompos berpengaruh terhadap diameter batang, dan volume akar yang pada umumnya terdaapat pada dosis $24.5 \mathrm{~g} /$ polybag (E2).

\section{Daftar Pustaka}

Agneesia. 2009, Pembuatan Kompos Eceng Gondok (Eichhornia crassipes (Mart) Solms.) dengan Penambahan Bioaktivator yang Berbeda dan Uji Kualitas Kompos pada Pertumbuhan Tanaman Cabai Merah (Capsicum annuum L.)

Darliah, I. Suprihatin, D.P. dw Vries, W. Handayani, T. Herawati, dan T.
Sutater. 2001. Variabilitas genetik, heritabilitas, dan penampilan fenotipik 18 klon mawar di Cipanas. J. Hort. 11(3):148-154.

Esdu, 2008. Perkembangan Tanaman. Yogyakarta : Pustaka Belajar.

Gabesius, Y.O., L.A.M. Siregar dan Y. Husni. 2012. Respon pertumbuhan dan produksi beberapa varietas kedelai (Glycine max (L) Merrill) terhadap pemberian pupuk bokashi. Jurnal Online Agroekoteknologi, 1(1): 220-236.

Jumrawati., 2008. Efektifitas Inokulasi Rhizobium sp. Terhadap Pertumbuhan dan Hasil Kedelai pada Tanah Jenuh Air. LIPI Press. Jakarta.

Lakitan, B.,2004. Dasar-dasar Fisiologi

Tumbuhan. PT Raja Grafindo

Persada. Jakarta.

Nyakpa, M.Y. Lubis, A.M. Pulung, M.A. Amroh, A.G, Munawar, A. Hong, G.B dan N. Hakim, 1988. Kesuburan Tanah. Universitas Lampung,S Bandar Lampung.

Purwanto, S. 2004. Kajian suhu ruang simpan terhadap kualitas benih kedelai hitam dan kedelai kuning. Skripsi. Universitas Gadjah Mada. Yogyakarta.

Ressi, A. 2015. Pengaruh Kompos Eceng Gondok dan Pupuk Fosfor Terhadap Pertumbuhan dan Produksi Kacang Hijau (Vigna radiata L.). Skripsi. Fakultas Pertanian Universitas Riau. Pekanbaru.

Sarief, S. 1986. Kesuburan dan Pemupukan Tanah Pertanian. Pustaka Buana. Bandung 
Suprapto, H.S. 2004. BertanamKedelai.

Penebar Swadaya.Jakarta.

Widianto. 2008. Balai Penelitian Kacang-

kacangan dan Umbi-Umbian.

Balitkabi.

Malang. 